\title{
Domestic violence: a Rodger's evolutionist conceptual analysis
}

\author{
Violência doméstica: análise conceitual evolucionista de Rodgers \\ Violencia doméstica: análisis conceptual evolutivo de Rodgers
}

\section{Victoria Grassi Bonamigo' ORCID: 0000-0002-3476-1970 \\ Deborah Ribeiro Carvalho' ORCID: 0000-0002-9735-650X \\ Marcia Regina Cubas' ORCID: 0000-0002-2484-9354}

'Pontifícia Universidade Católica do Paraná. Curitiba, Paraná, Brazil.

How to cite this article: Bonamigo VG, Carvalho DR, Cubas MR. Domestic violence: an Rodger's evolucionist conceptual analysis. Rev Bras Enferm. 2021;74(Suppl 3):e20200376. doi: http://dx.doi.org/10.1590/0034-7167-2020-0376

\section{Corresponding author:} Victoria Grassi Bonamigo E-mail:victoria.grassi@outlook.com

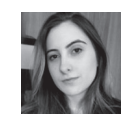

EDITOR IN CHIEF: Antonio José de Almeida Filho ASSOCIATE EDITOR: Fátima Helena Espírito Santo

Submission: 06-04-2020

Approval: 10-02-2020

\begin{abstract}
Objective: to analyze the concept of domestic violence based on its use in health sciences, humanities, and exact sciences according to Rodgers' evolutionary model. Methods: this is a concept analysis based on Rodgers' evolutionary conceptual model. Ninety-six articles were included in Portuguese, English, Spanish, and French, which had a definition of domestic violence, having identified the antecedents, attributes and consequences and produced a model case. Results: twenty-two attributes, ten antecedents and eight consequences were identified. Final considerations: from antecedents, attributes and consequences, it was possible to identify the connection between domestic violence and gender issues, especially patriarchal, being seen in a normalized way by society and causing consequences to the victims' physical and psychological health.

Descriptors: Standardized Nursing Terminology; Violence; Domestic Violence; Gender-Based Violence; Concept Formation.
\end{abstract}

\section{RESUMO}

Objetivo: analisar o conceito de violência doméstica baseado em sua utilização nas áreas das ciências da saúde, ciências humanas e ciências exatas segundo o modelo evolucionista de Rodgers. Métodos: análise de conceito baseada no modelo conceitual evolucionista de Rodgers. Foram incluídos 96 artigos nos idiomas português, inglês, espanhol e francês, que apresentavam definição de violência doméstica, tendo sido identificados os antecedentes, atributos e consequentes, sendo confeccionado um caso modelo. Resultados: foram identificados 22 atributos, dez antecedentes e oito consequentes. Considerações finais: a partir dos antecedentes, atributos e consequentes, foi possível identificar a ligação da violência doméstica com questões de gênero, especialmente de cunho patriarcal, sendo vista de forma normalizada pela sociedade, causando consequências à saúde física e psicológica da vítima. Descritores: Terminologia Padronizada em Enfermagem; Violência; Violência Doméstica; Violência de Gênero; Formação de Conceito.

\section{RESUMEN}

Objetivo: analizar el concepto de violencia intrafamiliar a partir de su uso en las áreas de ciencias de la salud, humanidades y ciencias exactas según el modelo evolutivo de Rodgers. Métodos: análisis de conceptos basado en el modelo conceptual evolutivo de Rodgers. se incluyeron 96 artículos en portugués, inglés, español y francés, los cuales tenían una definición de violencia doméstica, habiéndose identificado los antecedentes, atributos y consecuencias, y se realizó un caso modelo. Resultados: se identificaron 22 atributos, diez antecedentes y ocho consecuentes. Consideraciones finales: a partir de los antecedentes, atributos y consecuencias, se pudo identificar la conexión entre la violencia intrafamiliar y las cuestiones de género, especialmente de carácter patriarcal, siendo visto de manera normalizada por la sociedad, provocando consecuencias en la salud física y psicológica de la víctima.

Descriptores: Terminología Normalizada de Enfermería; Violencia; Violencia Doméstica; Violencia de Género; Formación de Concepto. 


\section{INTRODUCTION}

Terminology is understood as a controlled vocabulary composed of technical terms that represent concepts of a science or the systematization of knowledge in an field of knowledge. It is a technology that supports professional practice, as it aims to standardize communication, data collection, organization and analysis; therefore, it is characterized as structured, classifying, hierarchical and normalized ${ }^{(1-3)}$.

In nursing, terminology represents the universe of terms and their definitions, which is an integral and essential part of the theoretical and practical domain of the profession ${ }^{(4-5)}$. Nursing terminologies are instruments of nurses' work, since the standardization of terms facilitates communication between professionals, health documentation and data retrieval and comparison ${ }^{(4-5)}$. In the field of health documentation, an example of a benefit of using terminology in nursing is the ease of identifying and, consequently, notifying the authorities and intervening in cases of vulnerability to violence.

The International Classification for Nursing Practice (ICNP ${ }^{\circ}$ ), version 2019-2020, inserts the word "violence" 22 times in the Focus axis or in the definition of terms in Focus, Client and Environment axes. Moreover, it is part of pre-combined concepts of nursing interventions and diagnoses. Concerning diagnostic concepts, four are related to violence: Risk of being an Intimate Partner Violence Victim; Risk of Violence; Violence, Absent; Intimate Partner Violence Victim. These terms, hierarchically, are derived from the terms abuse and intimate partner violence and from the term violence as the main father term ${ }^{(6)}$.

The International Nurses Council encourages the production of terminological subsets for ICNP', with violence being the object of some of them ${ }^{(7-8)}$; however, since it is a terminology based on terms, definitions and concepts, it is necessary to deepen the meaning of the term, in order to include it in a subset. Thus, the following research guiding question was established: what is the application of the term domestic violence in the humanities, exact and health sciences?

The scope of this article aims to clarify the concept of interest, domestic violence, due to not being considered, so far, a concept in ICNP'. There is no consensus between using the term domestic violence. Some authors use it to refer to violence against women ${ }^{(9)}$, while others characterize it by the domestic environment in which such violence is perpetuated ${ }^{(10)}$. The nature of violence is also not consensual, considering that certain authors argue that domestic violence is restricted to physical violence ${ }^{(11)}$ and ICNP ${ }^{\circ}$ inserts, hierarchically, the term violence under aggressive behavior, which is defined as "brutal, arrogant action or attitude, expressed verbally, physically, or symbolically"(12).

In this context, using Rodgers' evolutionary theory, which considers the cyclicality of concepts and their use, is an opportunity. In her analysis, the author works with the construction of the concept of interest based on the relationship between attributes, antecedents, and consequences ${ }^{(13)}$.

\section{OBJECTIVE}

To analyze the concept of domestic violence based on its use in health sciences, humanities and exact sciences according to Rodgers' evolutionary model.

\section{METHODS}

\section{Ethical aspects}

This research did not require approval of a Research Ethics Committee, as it does not directly involve human beings, limiting itself using a publicly accessible database.

\section{Theoretical-methodological framework}

For Rodgers, a concept is the abstract cognitive representation, formed by a word or a set of them, that summarizes the essence of a certain phenomenon in a way that, even out of context with a theory, contributes to knowledge maintenance ${ }^{(13-14)}$. The author argues that concepts are cyclical, highlighting three aspects that influence the concept cycle: its meaning, its use and its application. Its meaning is related to the utility that the concept presents within a human practice, its use is related to the situation in which the concept is used and its application corresponds to the scope in which it is appropriate for use. Thus, Rodgers' evolutionary conceptual analysis aims to elucidate the application of a concept ${ }^{(13)}$.

Such an approach has a dynamic and broad character, considering the contextual importance of the concept. Its methodological process is qualitative, inductive, organized in definition of the concept of interest, establishment of a strategy for data collection, data collection and organization, data analysis and construction of model cases ${ }^{(13-16)}$.

Rodgers' evolutionary conceptual analysis methodology considers that the definition of the concept of interest is part of the methodological process, due to the contextual study that allows researchers to choose the term that most closely matches the concept they wish to study. This contextual study also anchors the construction of data collection, especially the choice of the means of collection, which refers to the type of material that will be included in this analysis, which may be scientific articles, gray material, reports from focus groups and other documents ${ }^{(13,17)}$. The alignment between the means of collection and the guiding question guarantees conceptual analysis and the contextualization of the term. The selection, inclusion and exclusion criteria for these materials should start from the guiding question and analysis objective ${ }^{(13,17)}$. In this case, research authors who used concept analysis do not describe the literature review using rules or checklist ${ }^{(14-15)}$, being identified, including, data collection through focus group ${ }^{(17)}$.

It must be carried out carefully after finalizing the definition of the data collection strategy. It should be noted that, in a conceptual analysis, the definitions of the concept of interest are extracted from the material that met the inclusion criteria previously established, and should be organized in a way that it is possible to identify and access its source, if necessary. Following, the identification of attributes, antecedents and consequences in the definitions that make up the corpus of conceptual analysis.

The categorical term attribute refers to defining characteristics, in general terms, of the phenomenon illustrated by the concept of interest ${ }^{(13)}$. They have direct connections with said antecedents and consequences of a concept. The categorical term antecedent 
refers to a phenomenon that precedes the concept of interest, whereas the categorical term consequent refers to a phenomenon that succeeds the concept of interest ${ }^{(13)}$.

To illustrate this relationship, Rodgers proposes the creation of a model case that meets all the attributes, consequences and antecedents identified in the corpus of analysis. This elaboration should preferably be inserted in the context in which the concept of interest was analyzed ${ }^{(13)}$.

\section{Methodological procedures}

The research design used was based on the stages of Rodgers' evolutionary conceptual analysis ${ }^{(13)}$. It is noteworthy that this research is part of a matrix project entitled "Terminologia padronizada em enfermagem: construção e aprimoramento de subconjuntos da Classificação Internacional para a Prática de Enfermagem (ICNP $)^{\circ}$ ".

\section{Interest concept identification}

As an empirical basis, the ICNP' terminology subset proposal, prepared by Albuquerque, was entitled "Terminologia da enfermagem caracterizadora da violência doméstica contra crianças e adolescentes $^{\prime \prime(8)}$. In one of the articles, product of the aforementioned thesis, it was evidenced that the victimization of domestic violence is a phenomenon of decisive character in the social scope of the health-disease process ${ }^{(8)}$. This manuscript highlights the contradiction between the formal logic of identifying terms for the elaboration of the subset and the dialectical logic, which recognizes the dynamics of the phenomena and their historical foundations. Thus, a conceptual analysis of the concept of interest, domestic violence, was proposed to improve the operational concept and possible inclusion as a pre-combined concept, ICNP ${ }^{\circ}$ nursing diagnosis.

\section{Data collection}

The data collection strategy was defined based on the understanding that domestic violence is not an exclusive health phenomenon; therefore, using scientific articles from different fields of knowledge was stipulated. The database chosen was the Platform of Journals of the Coordination for the Improvement of Higher Education Personnel (CAPES - Coordenação de Aperfeiçoamento de Pessoal de Nível Superior). CAPES contemplates the different fields of knowledge and has access to journals through PubMed/MEDLINE.

The search was carried out using the structured descriptor "domestic violence". In the advanced options, it was determined that articles, journal articles and peer-reviewed reference entries, published in 2018 in English, Portuguese, Spanish, and French, would be selected. Three refinement themes were chosen for the structured descriptor, namely: domestic violence, family violence and intimate partner violence. The articles found through this search met the selection criteria for reading in full.

As an inclusion criterion, the article should present a clear definition of the concept of interest. By clear definition, it is understood that the concept of interest is as subject of prayer. The exclusion criterion established was the presence of the definition of the concept of interest simultaneously with another concept. With that, corpus of analysis was composed.

Each definition belonging to the corpus of analysis received an index number for the researchers' organization. The definitions were organized in an electronic spreadsheet. Each row represented a definition, and the columns, the following data: index number, title of the article of origin, authorship of the article of origin, reference of the definition, if any, and link to access the article from which it was extracted.

\section{Data analysis}

In each definition, the text fragment, if any, was identified, referring to the attributes, antecedents and consequences, using Rodgers ${ }^{(13)}$ as a theoretical framework. Simultaneously, these fragments were included in another spreadsheet that contained three columns, one for each categorical term.

In order to identify the field of knowledge of the definitions that made up the corpus of conceptual analysis, the curriculum of the authors of the references used in the definitions extracted from the articles was accessed. If there was no reference, the curriculum of the authors of the article itself was consulted, considering the definition extracted from their own authorship. The definitions were classified into health sciences, humanities, exact sciences and multidisciplinary, in the event that it was not possible to identify only one field of knowledge.

\section{Model case development}

The model case made is fictitious, being prepared in isolation by one of the researchers and suitable by three professors and seven students from the study group of the researchers' graduate program. The study meets all the antecedents, attributes and consequences identified in the data analysis, illustrating the conceptual analysis ${ }^{(13)}$.

\section{RESULTS}

\section{Data collection}

The search for the descriptor and for the advanced tools resulted in 847 articles that met the selection criteria for reading, of which 97 presented a clear definition of domestic violence; however, an article was excluded for bringing the definition of the concept of interest and, concomitantly, of another type of violence.

Of the 96 articles, 122 definitions were extracted, of which 26 articles presented more than one. Conceptual analyzes that used the same methodology used a less extensive corpus of analysis, such as the "child growth" conceptual analysis, with 41 concepts composing the corpus of analysis ${ }^{(14)}$ and "cancer survivor", with 39 definitions ${ }^{(15)}$. By simple arithmetic mean, each article brought 1.27 definition. With regard to the fields of knowledge, the articles included were mostly in the field of health sciences (45\%) and human sciences (45\%). The exact sciences contributed $1 \%$ of the articles. In $9 \%$ of the articles, it was not possible to establish a specific field, as the definitions were elaborated from definitions of several fields (multidisciplinary). 


\section{Data analysis}

From analysis of the corpus formed by the 122 definitions extracted, 22 attributes were identified for the term domestic violence, ten antecedents and eight consequents. The list of terms is shown in Chart 1.

Chart 1 - Antecedents, attributes, and consequents of the term domestic violence

\begin{tabular}{|c|c|}
\hline Antecedents & $\begin{array}{l}\text { Patriarchate culture; gender and sexuality issues; } \\
\text { power and authority; conflict; victim over the age of } \\
\text { 16; cohabitation with the offender; male and female } \\
\text { manifestation; dominant male position; racial, ethnic, } \\
\text { religious, economic and social contexts; being or } \\
\text { living as a family. }\end{array}$ \\
\hline Attributes & $\begin{array}{l}\text { Any behavior that causes physical or psychological } \\
\text { injury to an intimate partner; coercive control; } \\
\text { physical, sexual or psychological violence; abuse; } \\
\text { deprivation of services, freedom or leisure; } \\
\text { degradation or offense to a romantic partner; } \\
\text { intimate partner violence; serious violation of } \\
\text { human rights; any intentional act by one family } \\
\text { member to another to limit their legal rights; male } \\
\text { domination and control over women; main reason } \\
\text { for referring children to state child welfare services } \\
\text { in advanced industrialized countries; affects about } \\
\text { a third of women in the world; abuse of power or } \\
\text { authority; considered a moralistic form of justice; } \\
\text { normalized by society; any act of violence based on } \\
\text { gender, which may occur in public or in private life; } \\
\text { a crime that must be dealt with privately between } \\
\text { the parties, punishing offenders and protecting } \\
\text { the victim from further abuse; systematic pattern } \\
\text { of power and control perpetuated by an intimate } \\
\text { partner; police and community responsibility; } \\
\text { complex phenomenon of systematic structure; } \\
\text { repetitive process that gets worse during a } \\
\text { relationship; defined by law as offenses. }\end{array}$ \\
\hline Consequents & $\begin{array}{l}\text { Health impact; psychological, physical, sexual, } \\
\text { reproductive damage and, in some cases, death; } \\
\text { domination of women; female loss in the choice } \\
\text { in relation to her health; long-term consequences } \\
\text { for individuals and society; establishment of power } \\
\text { and control; depression and post-traumatic stress } \\
\text { syndrome; normalization of violence. }\end{array}$ \\
\hline
\end{tabular}

The definitions presented antecedents related to the gender theme, citing the position of men as dominant towards women, manifestations of women and men $^{(18-23)}$. In this regard, feminist structuralist theory was referred to when addressing patriarchy culture as one of the domestic violence antecedents ${ }^{(20)}$.

Regarding the context of violence, the antecedents identified refer to that which occurs within the family ${ }^{(18,24-26)}$, in which there is cohabitation with their offenders, informing the victim's age as over 16 years old ${ }^{(18,26)}$. Antecedents indicate that domestic violence can occur in several realities, regardless of economic, religious, racial, ethnic and social circumstances ${ }^{(27-29)}$.

The attributes of the analyzed definitions related the concept of interest to intimate partner violence and violence against women, with structural gender issues mentioned, in which men have more power than women ${ }^{(19,29-31)}$. As for the modalities of violence recognized in the context of domestic violence, they demonstrate the recognition of physical, psychological, sexual and economic violence ${ }^{(32-33)}$. Among the attributes collected, it stands out that it is considered a form of justice and normalized by society, despite being classified as a complex phenomenon that must be dealt with at the police and judicial levels ${ }^{(34-36)}$.

With regard to the consequences, the implication of domestic violence in health is highlighted, which can often cause psychological damage, such as depression and post-traumatic stress disorder; as to the damage to victims' physical health, they are always represented in the female sex ${ }^{(37)}$. It is also mentioned that domestic violence causes the violence to normalize for the victim, corroborating what was identified in the attributes and antecedents ${ }^{(38)}$.

\section{Model case}

Maria, 45 years old, is married to João, 51 years old, and the couple has two adolescent daughters who follow strict rules set by their father. João works as an administrative assistant in a company, while Maria takes care of the house and complements the income by selling clothes she sews. He believes that women should wear long skirts and always go out with their husbands, who, in turn, should look after the family. In the name of zeal, João makes Maria always warn him when she will have activities outside the home, even routine ones, like going to her mother's house, to the church and to the supermarket. On Sundays, the family attends mass in the morning; however, one Sunday, Alicia, the couple's daughter, decided not to go with them, as she felt unwell. Maria agreed that the girl should stay at home, but John ordered Alicia to get up and go to mass. Maria disagreed and the two started to argue. He stated that he was the "man of the house", so everyone would be subject to his orders, and that he did not want Alicia to deviate from the paths of good customs. The wife argued that the daughter was ill and he slapped her, ordering her to be quiet. Maria obeyed and Alicia went to church with her family. Maria presents a depression chart, caused by her husband's episodes of violence, undergoing treatment at a Psychosocial Service Center (CAPS - Centro de Atendimento Psicossocial), but she says she knows she is guilty of these events and that her husband is right, as the goal is to watch over the family.

\section{DISCUSSION}

\section{Antecedents}

The findings corroborate the statement that domestic violence is a complex phenomenon ${ }^{(36)}$, as the definitions consider that it is a phenomenon that involves human subjectivity. There are clear gender issues that permeate this concept, often used as a synonym for violence against women, turning to the need to understand gender issues and the social organization that is maintained based on this structure.

Gender is a primary way of giving meaning to power relations, of articulating power and of building power ${ }^{(39)}$. Thus, even generic attributes, which do not refer directly to power, are related to this concept when placed in the context of violence, since it is the maximum expression of gender inequality ${ }^{(39-40)}$. Considering this scenario, it can be said that domestic violence is structural violence, in which abused individuals are oppressed, naturalizing the process 
of violence that affects them ${ }^{(41)}$. These questions explain, in part, the fact that when searching literature for the term domestic violence, there are researches related to gender violence.

In ICNP ${ }^{\circ}(6)$, the word gender has three relations: the role of the individual in a society, personal identity and discrimination. In none of these relationships does violence or issues of power by virtue of gender stand out. In this sense, the identification of attributes that highlight gender is an important contribution to the formation of the concept of domestic violence to be incorporated into the classification..

Regarding the victim's profile, the background identified leads to the conclusion that the term domestic violence is applied to people over 16 years old, supporting a concept of intrafamily child abuse proposed by Minayo. The author uses the term intrafamily to classify a violent acts that occur within domestic environments against children ${ }^{(42)}$. This result also corroborates with the findings about the cultural representation of the phenomenon of domestic violence as violence between a heteronormative couple ${ }^{(43)}$. However, it is highlighted that this issue remains a research gap, requiring further investigation due to disagreements between different fields of knowledge, theoretical, and cultural frameworks.

In ICNP', elderly people and children are represented by concepts that lead to the terms Victim and Abuse; therefore, the nursing diagnoses Elder Abuse Victim and Child Abuse Victim are used to refer to the violence perpetrated in these two generational groups. Using such terms is justified by the vulnerability, understanding that abuse, hierarchically, is a form of violence directed at groups called victims.

Based on the identified background, it is necessary that the concept of domestic violence be differentiated from the term Abuse. When analyzing the attributes, it is verified that the former is predominantly related to gender and power relations inserted in family spaces or cohabitations and in racial, ethnic, religious, economic and social contexts. In turn, in ICNP', abuse is directed at vulnerable generational groups.

\section{Attributes}

As presented in the case study structured in this research, the concept of domestic violence tends towards violence against adult women, reinforcing the victim profile traced from the identification of antecedents. In the case of attributes, offenders, predominantly, are intimate partners who live in the family environment. In this perspective, the context to be overcome is discussed, in which female participation in society is restricted to the private environment, for which it is responsible for administration, in a patriarchal system with submission to men ${ }^{(44-45)}$. This organization of social roles based on gender is idealized, which makes violence conducive, as offenders justify violent acts by not fulfilling the idealized social role of the victim, using psychological, moral, physical, sexual or financial violence as a way repetitive punishment, tending to cyclical aggravation and culminating in homicide ${ }^{(44)}$. The progression of this normative punishment is noticeable from the identification of attributes such as coercive control, deprivation of services, systematic pattern of power and perpetuated control and a repetitive process that worsens during the relationship.
Such a set of attributes must be taken into account when describing the concept of Domestic Violence; however, it highlights the gap identified in the literature that made up the corpus of analysis that was restricted to attributes in heteronormative relationships.

\section{Consequents}

The identified consequences point to the community repercussion of the perpetration of domestic violence. Although it is argued that not all women are violated by their gender, all fear being potential victims, in the absence of State intervention, and give in to the power that permeates this violence as an act of self-protection ${ }^{(46)}$. Considering the profile of victims and the contextualization of the violent act identified through the attributes and antecedents of this study, it is possible to infer that one of the main consequences of the perpetration of domestic violence, for the community, is normalization and maintenance of the patriarchal system, which begins from the moment when victims are silent in an attempt to prevent the violence suffered ${ }^{(46)}$.

The progression of violence was analyzed in Atlas of Violence ${ }^{(47)}$. Women homicides between 2007 and 2017 increased by $30.7 \%$ in relation to the previous decade. On the other hand, Atlas presents a problematization of the inefficiency of using aggregated health data to characterize these homicides or as feminicides - when there is an initial intention to kill, or as lethal violence against women - when there is no initial intention to kill. This is due to the terminology adopted by the Ministry of Health, the International Disease Code (IDC), which does not characterize violence due to its motivation ${ }^{(47)}$.

The analysis made it possible to highlight the concept of domestic violence as a child term of the term violence in ICNP', enabling clarification of its specificities through the composition of attributes, antecedents, and consequences. Next step is directed to the construction of the operational concept and its validation.

\section{Study limitations}

The limitation of this study is related to the cross-section of data collection, using articles from 2018. This limitation was minimized by using source references and the number of definitions found.

\section{Contributions to nursing}

Although it is understood that domestic violence is a phenomenon that requires interdisciplinary and intersectoral coping, victims are assisted by the nursing staff in intra and extra-hospital spaces. To identify the phenomenon, which is often invisible, it is necessary that nurses, as care coordinators, understand the breadth of the term's origin. Thus, the contribution to nursing is made explicit by a better elaboration of the concept of interest, which is the focus of attention in nursing.

\section{FINAL CONSIDERATIONS}

From the analysis carried out, it is considered that the term domestic violence is related to antecedents that address issues 
of gender, race/ethnicity and social class, in spaces of power. Offenders tend to be an authoritative figure with power and a member of the victim's family, who is characterized as an adult woman, referring to the patriarchal organization of society. Domestic violence, psychological, sexual, physical or economic violence, as well as deprivation of freedom and access to services are considered. This violence concerns the pattern of control between intimate partners, which tends to be normalized by a patriarchal society. The identified consequences point to community repercussions and victims' physical and emotional health. The analysis carried out refers to the Domestic Violence concept limitation, not including the phenomenon in different generational groups, which for ICNP ${ }^{\circ}$ are covered in terms related to abuse, nor discussing the presence of non-heteronormative relationships.

\section{REFERENCES}

1. Rodrigues DS. Definição terminológica: princípios e regras. Rev Moara [Internet]. 2020[cited 2020 Aug 14];5(1):19-36. Available: https:// periodicos.ufpa.br/index.php/moara/article/view/9040

2. Pavel S, Nolet D. Manual de terminologia: teoria e prática [Internet]. Montreal: The Translation Bureau; 2002; 17-20 [cited 2020 Apr 20]. Available from: https://linguisticadocumentaria.files.wordpress.com/2011/03/pavel-terminologia.pdf

3. Vakulenko M. Term and terminology: basic approaches, definitions, and investigation methods (Easterm-European perspective). Terminol Sci Res [Internet]. 2014[cited 2020 Aug 14];24(Jan-2014):12-28. Available from: http://ekmair.ukma.edu.ua/handle/123456789/

4. Cavalcante MDMA, Larocca LM, Chaves MMN, Cubas MR, Piosiadlo LCM, Mazza VA. Nursing terminology as a work process instrument of nurses in collective health. Rev Esc Enferm USP. 2016;50(4):607-613. doi:10.1590/S0080-623420160000500010

5. Garcia TR. ICNP ${ }^{\oplus}$ : a standardized terminology to describe professional nursing practice. Rev Esc Enferm USP. 2016;50(3):378-9. doi: 10.1590/ S0080-623420160000400001

6. International Council of Nurses. International Classification for Nursing Practice - ICNP® [Internet]. Geneve: ICN; 2019 [cited 2020 Apr 16]. Available from: https://www.icn.ch/what-we-do/projects/ehealth/icnp-browser

7. Albuquerque LM, Carvalho CMG, Apostólico MR, Sakata KN, Cubas MR, Egry EY. Nursing Terminology defines domestic violence against children and adolescents. Rev Bras Enferm. 2015;68(3):452-9. doi: 10.1590/0034-7167.2015680311i

8. Sakata-so KN, Gomes M, Egry EY, Regina M, Albuquerque LM. Subconjunto terminológico para o enfrentamento da violência doméstica contra a criança: um estudo de validação[Internet]. In: $8^{\circ}$ Congresso Ibero-Americano em Investigação Qualitativa; 2019; Lisboa, Portugal. Aveiro: CIAIQ. 2019 [cited 2020 Apr 20]. Available from: https://www.proceedings.ciaiq.org/index.php/CIAIQ2019/article/view/2174.

9. Bridges AJ, Karlsson ME, Jackson JC, Andrews AR, Villalobos BT. Barriers to and methods of help seeking for domestic violence victimization: a comparison of Hispanic and non-Hispanic white women residing in the United States. Violence Against Women. 2018;24(5):1810-29. doi: $10.1177 / 1077801218754409$

10. Walby S, Towers J. Untangling the concept of coercive control: theorizing domestic violent crime. Criminol Crim Justice. 2018;18(1):7-28. doi: $10.1177 / 1748895817743541$

11. Yousefnia N, Nekuei N, Farajzadegan Z. The relationship between healthcare providers' performance regarding women experiencing domestic violence and their demographic characteristics and attitude towards their management. J Inj Violence Res. 2018;10(2):113-8. doi: 10.5249/jivr.v10i2.958

12. Rodgers BL. Concepts, analysis and the development of nursing knowledge: the evolutionary cycle. J Adv Nurs. 1989;14(4):330-5. doi: 10.1111/j.1365-2648.1989.tb03420.x

13. Sousa LMM, Firmino CF, Carteiro DMH, Frade F, Marques JM, Antunes AV. Análise de conceito: conceitos, métodos e aplicações em enfermagem. Rev Investig Enferm[Internet] 2018[cited 2020 Apr 20];9-19. Available from: https://www.researchgate.net/profile/Luis_Sousa20/publication/330205622_ ANALISE_DE_CONCEITO_CONCEITOS_METODOS_E_APLICACOES_EM_ENFERMAGEM/links/5c33d6fc458515a4c7151840/ANALISE-DE-CONCEITOCONCEITOS-METODOS-E-APLICACOES-EM-ENFERMAGEM.pdf

14. Monteiro FPM, Araujo TL, Cavalcante TF, Leandro TA, Sampaio Filho SPC. Child growth: concept analysis. Texto Contexto Enferm. 2016;25(2):1-9. doi: 10.1590/0104-07072016003300014

15. Oliveira RAA, Conceição VM, Araujo JS, Zago MMF. Concept analysis of cancer survivorship and contributions to oncological nursing. Int J Nurs Pract. 2018;24(1):1-8. doi:10.1111/ijn.12608

16. Barry A, Heale R, Pilon R, Lavoie AM. The meaning of home for ageing women living alone: an evolutionary concept analysis. Health Soc Care Community. 2018;26(3):e337-44. doi: 10.1111/hsc.12470

17. Callaghan JEM, Alexander JH, Sixsmith J, Fellin LC. Beyond "witnessing": children's experiences of coercive control in domestic violence and abuse. J Interpers Violence. 2015;1-31. doi: 10.1177/0886260515618946

18. Um MY, Kim HJ, Palinkas LA. Correlates of domestic violence victimization among North Korean refugee women in South Korea. J Interpers Violence. 2018;33(13):2037-58. doi: 10.1177/0886260515618946

19. Kim HJ, Atteraya MS, Yoo HY. Women's agency freedom through empowerment against domestic violence: evidence from Nepal. Int Soc Work. 2018;62(3):1088-103. doi: 10.1177/0020872818767255

20. Pun KD, Rishal P, Infanti JJ, Bjørngaard JH, Koju R, Schei B, et al. Exposure to domestic violence influences pregnant women's preparedness for childbirth in Nepal: a cross-sectional study. PLoS One. 2018;13(7):1-20. doi:10.1371/journal.pone.0200234 
21. Bloom A. A new "shield of the weak": continued paternalism of domestic violence services in Uruguay. Violence Against Women. 2018;24(16):1949-66. doi: 10.1177/1077801218757374

22. Jeremiah RD, Quinn CR, Alexis JM. Lessons learned: evaluating the program fidelity of UN Women Partnership for Peace domestic violence diversion program in the Eastern Caribbean. Eval Program Plann. 2018;69:61-7. doi: 10.1016/j.evalprogplan.2018.03.008

23. El Abani S, Pourmehdi M. Gender and educational differences in perception of domestic violence against women among Libyan migrants in Manchester. J Interpers Violence. 2018;1-23. doi: 10.1177/0886260518760006

24. Hajare RA. Domestic violence perpetration reporting among recently-married men residing in Slums correlate pharmaceutical institution in South West Pune, India. Orthop Sport Med Open Access J. 2018;1(3):46-7. doi: 10.32474/osmoaj.2018.01.000112

25. McCarthy M, Bates C, Triantafyllopoulou P, Hunt S, Milne Skillman K. "Put bluntly, they are targeted by the worst creeps society has to offer": police and professionals' views and actions relating to domestic violence and women with intellectual disabilities. J Appl Res Intellect Disabil. 2019;32(1):71-81. doi: 10.1111/jar.12503

26. Dewey M, Heiss SN. Inclusive branding strategies for domestic violence agencies: embracing opportunities to reach and better serve maleidentified survivors. J Interpers Violence. 2018;33(9):1427-48. doi: 10.1177/0886260515618213

27. Bhandari S, Sabri B. Patterns of abuse among South Asian women experiencing domestic violence in the United States. Int Soc Work. 2018;63(1):55-68. doi: 10.1177/0020872818767250

28. Sullivan CM. Understanding how domestic violence support services promote survivor well-being: a conceptual model. J Fam Violence. 2018;33:123-31. doi: 10.1007/s10896-017-9931-6

29. Diette TM, Ribar DC. A longitudinal analysis of violence and housing insecurity. Econ Inq. 2018;56(3):1-20. doi: 10.1111/ecin.12571

30. Tsirigotis K, Łuczak J. Resilience in women who experience domestic violence. Psychiatr Q. 2018;89(1):201-11. doi: 10.1007/ s11126-017-9529-4

31. Victor BG, Resko SM, Ryan JP, Perron BE. Identification of domestic violence service needs among child welfare-involved parents with substance use disorders: a gender-stratified analysis. J Interpers Violence. 2018;1-23. doi: 10.1177/0886260518768569

32. Gupta PP, Bhandaria R, Khanal V, Gupta S. Universal health coverage: there is more to it than meets the eye. J Fam Med Prim Care. 2018;7(3):542-5. doi: 10.1007/s11126-017-9529-4

33. Misso D, Schweitzer RD, Dimaggio G. Metacognition: a potential mechanism of change in the psychotherapy of perpetrators of domestic violence. J Psychother Integr. 2019;29(3):248-60. doi: 10.1037/int0000111

34. Belknap J, Grant D. Fifty years after the 1967 Crime Commission Report: how nonpolicing domestic violence research and policies have changed and expanded. Criminol Public Policy. 2018;17(2):467-81. doi: 10.1111/1745-9133.12370

35. Tenkorang EY, Owusu AY. A life course understanding of domestic and intimate partner violence in Ghana. Child Abus Negl. 2018;79:384-94. doi: 10.1016/j.chiabu.2018.02.027

36. Flynn C, Damant D, Lapierre S, Lessard G, Gagnon C, Couturier V, et al. When structural violences create a context that facilitates sexual assault and intimate partner violence against street-involved young women. Womens Stud Int Forum. 2018;68(Jan):94-103. doi:10.1016/j. wsif.2018.01.004

37. Tonsing J. Fijian women's experiences of domestic violence and mothers' perceived impact of children's exposure to abuse in the home. Int Soc Work. 2018;63(1):76-86. doi: 10.1177/0020872818775474

38. Xie L, Eyre SL, Barker J. Domestic violence counseling in rural Northern China: gender, social harmony, and human rights. Violence Against Women. 2018;24(3):307-21. doi: 10.1177/1077801217697207

39. Scott J. Gênero, uma categoria útil de análise histórica. Educ Real [Internet]. 1995;20(2):71-99. [cited 2020 Apr 20] Available from: https:// www.seer.ufrgs.br/educacaoerealidade/article/viewFile/71721/40667.

40. Boyle K. What's in a name? Theorising the Inter-relationships of gender and violence. Fem Theory. 2019;20(1):19-36. doi: 10.1177/1464700118754957

41. Minayo MCS. Violência social sob a perspectiva da saúde pública. Cad Saude Publica. 1994;10(1):7-18. doi: 10.1590/s0102-311×1994000500002

42. Minayo MCS. Violência contra crianças e adolescentes: questão social, questão de saúde. Rev Bras Saúde Matern Infant. 2001;1(2):91-102. doi: 10.1590/s1519-38292001000200002

43. Rocha Gutmann VL, Silva CD, Acosta DF, Mota MS, Costa CFS, Vallejos CCC. Social representations of Primary Health Care users about violence: a gender study. Rev Gaúcha Enferm. 2020;41:e20190286. doi: 10.1590/1983-1447.2020

44. Carvalho MHP, Maia MMM. As janelas quebradas da violência doméstica. Rev Polit Judic Gestão Adm Justiça [Internet]. 2019 [cited 2020 Apr 20];5(2):18-37. Available from: https://www.indexlaw.org/index.php/revistapoliticiajudiciaria/article/view/6003/pdf

45. Martins APA. O sujeito "nas ondas" do feminismo e o lugar do corpo na contemporaneidade. Rev Café Com Sociol [Internet]. 2015[cited 2020 Apr 20];4(1):231-45. Available from: https://revistacafecomsociologia.com/revista/index.php/revista/article/view/443/pdf_1

46. Butler, J. Problemas de gênero: feminismo e subversão da identidade. 8. ed. Rio de Janeiro: Civilização Brasileira; 2018.

47. Cerqueira D, Bueno S, Lima R, Neme C, Ferreira H, Alves P, et al. Atlas da violência 2019 [Internet]. Brasília: Instituto de Pesquisa Econômica Aplicada; 2019 [cited 2020 Apr 25]. Available from: http://www.ipea.gov.br/portal/images/stories/PDFs/relatorio_institucional/190605_atlas_da_violencia_2019.pdf 